\title{
Identification and Characterization of Black Carbon Aerosol Sources in the East Baltic Region
}

\author{
Steigvilè Byčenkienė, Vidmantas Ulevicius, Vadimas Dudoitis, and Julija Pauraitė \\ Center for Physical Sciences and Technology, Savanoriu 231, LT-02300 Vilnius, Lithuania \\ Correspondence should be addressed to Vidmantas Ulevicius; ulevicv@ktl.mii.lt
}

Received 19 February 2013; Accepted 27 April 2013

Academic Editor: Giulia Pavese

Copyright (C) 2013 Steigvilè Byčenkienè et al. This is an open access article distributed under the Creative Commons Attribution License, which permits unrestricted use, distribution, and reproduction in any medium, provided the original work is properly cited.

\begin{abstract}
One-year continuous measurements of aerosol black carbon (BC) at the background site Preila $\left(55^{\circ} 55^{\prime} \mathrm{N}, 21^{\circ} 00^{\prime} \mathrm{E}, 5 \mathrm{~m}\right.$ a.s.l., Lithuania) were performed. Temporal and spatial evolution and transport of biomass burning (BB) and volcanic aerosols observed within this period were explained by the air mass backward trajectory analysis in conjunction with the fire detection data produced by the MODIS Rapid Response System and AERONET database. The surface measurements and analysis of the Angström exponent of the absorption coefficient done separately for shorter and longer wavelengths (i.e., $\alpha=370-520 \mathrm{~nm}$ and $\alpha=660-950 \mathrm{~nm}$ ) showed that high levels of aerosol BC were related to the transport of air masses rich in BB products from Ukraine caused by active grass burning. During the events the highest mean values of the Angström exponent of the absorption coefficients $\alpha_{370-520}$ and $\alpha_{590-950} \mathrm{~nm}$ were observed $(2.4 \pm 0.1$ and $1.5 \pm 0.1$, resp.). The ash plume of the Grimsvötn eruption on May 21, 2011 offered an exceptional opportunity to characterize the volcanic aerosols. The largest ash plume (in terms of aerosol optical thickness) over Lithuania was observed at May 24/25, 2011. The highest values of the Angström exponent of the absorption coefficients $\alpha_{370-520}$ and $\alpha_{590-950} \mathrm{~nm}$ were reached $(1.3 \pm 0.1$ and $1.4 \pm 0.1$, resp.).
\end{abstract}

\section{Introduction}

Atmospheric aerosol particles, which are very small and suspended in the air, affect Earth's climate directly by scattering and absorbing the atmospheric radiation and indirectly by acting as cloud condensation nuclei and modifying the optical properties of clouds. Furthermore, human exposure to fine particulate matter is associated with adverse impacts on human health [1-3] and the environment (climate, visibility, and biogeochemical cycles) [4].

High concentrations of carbonaceous particles, containing BC or organic compounds (OC) (organic carbon), are found mainly in the submicron size range. The main natural sources of $\mathrm{BC}$ are volcanic eruptions, forest fires, and so forth. Wildfires (biomass burning) emit a variety of trace gases and particulates [5-9]. The growing recognition of $\mathrm{BB}$ as a widespread and significant agent of change in Earth's system has led to an ongoing need for fire data on the regional, continental, and global scale. Due to high sorption capacity and optical properties, black carbon originated from $\mathrm{BB}$ is of great importance to the atmosphere processes and is a good indicator of anthropogenic air pollutants. Black carbon from $\mathrm{BB}$ alters chemical and physical properties of the atmosphere and snow albedo.

The eruption of Grimsvötn in Iceland (May 21, 2011) initiated a great number of research activities to characterize the physical, chemical, and optical properties of airborne volcanic material associated with this eruption. The main challenge in measuring volcanic material in the surface air is that this material is always mixed with other pollutants present in the air. A large fraction of carbonaceous component of the aerosol (in upper troposphere/lower stratosphere) was identified by Murphy et al. [10] and Martinsson et al. [11]. Volcanic eruptions inject large quantities of ash and gases into the atmosphere. Despite the evident significances of carbonaceous aerosol in air chemistry and physics, information concerning their temporal variability is still quite incomplete.

The long-range transport (LRT) of atmospheric particulate matter (PM) is a transboundary problem that can have significant impacts on $\mathrm{PM}_{10}$ and $\mathrm{PM}_{2.5}$ levels in background 
European areas [12]. LRT can cause high $\mathrm{PM}_{2.5}$ concentration peaks when air masses arrive under suitable meteorological conditions from regions with high emissions of particles and/or their precursor gases. Many research studies have been performed and reported for the background atmospheric monitoring of LRT [13-15]. Long-range transport of emissions from agricultural fires and volcanoes to Europe was recognized previously in USA, Europe, and Russia [1620]. In addition to European transport, LRT of smoke from Russian biomass burning has been recorded in Mongolia, China, Japan, and Korea [21], and studies have revealed that hemispheric-scale transport is possible [16]. As the mass concentrations of fine particles are commonly lower in Northern Europe countries compared with those in Central Europe [22, 23], LRT can have a notable impact on the aerosol particle levels under favorable conditions [23, 24]. The LRT of emissions from wildfires from the Ukraine and European part of Russia frequently increases the particulate matter concentrations in these countries during spring and summer [25-27]. Volcanic dust plumes can also be transferred over long distances by air masses, affecting the air quality not only over Europe but in other parts of the world as well [28].

Combining the variety of terrestrial information operationally derived from satellite data including those from NASA's MODIS instrument enables linking the different temporal and spatial scales. The use of the Angström exponent $\alpha$ has significantly increased in the last years, because this parameter is easily estimated using automated-surface sun photometry, while it is becoming increasingly accessible to satellite retrievals [29]. Moreover, the value of the Angström exponent is a qualitative indicator of the aerosol particle size or fine mode fraction [30].

In this work, the pollution events due to biomass burning that occurred in Lithuania on March 21-25, 2011 and pollution episode caused by long-range transported volcanic material from the Grimsvötn eruption that took place at the end of May 2011 in Iceland were investigated. Air mass backward trajectories, fire satellite observations, dispersion modeling results, and emission source data were used to identify the source. The mass and number concentrations of $\mathrm{PM}_{2.5}$ in conjunction with Angström exponent of the absorption coefficient and other optical properties of aerosol were studied.

\section{Methodology}

2.1. Site Description. The aerosol particle concentration measurements were performed at the Preila environmental pollution research station $\left(55^{\circ} 55^{\prime} \mathrm{N}, 21^{\circ} 00^{\prime} \mathrm{E}, 5 \mathrm{~m}\right.$ above sea level) in the coastal/marine environment. This station is located on the Curonian Spit, which separates the Curonian Lagoon and the Baltic Sea, and thus can be characterized as a regionally representative background area. The Curonian Lagoon, the largest coastal bay in the Baltic Sea, is a highly eutrophied water body. One of the nearest industrial cities, Klaipeda, is at a distance of about $40 \mathrm{~km}$ to the north, and the other major city, Kaliningrad, is $90 \mathrm{~km}$ to the south from Preila.

2.2. Long-Range Transport and Air Mass Backward Trajectories. Air mass backward trajectory analysis provides a better understanding of air flow and long-range transport patterns during the events. We analyzed the aerosol characteristics with respect to categorized air mass backward trajectories for the initial estimation of the wildfire and volcanoes potential source locations and quantitative contribution. Backward trajectories were produced using the Flextra model (NILU; Institute of Meteorology and Geophysics, Vienna) [31] and meteorological data provided from ECMWF (European Centre for Medium Range Weather Forecast). The potential source areas of long-range transported pollution were studied using 7-day backward air mass trajectories with a starting height of 500,1000, and $1500 \mathrm{~m}$ above the ground level. Trajectories were produced at $6 \mathrm{~h}$ intervals for each event. The height along the trajectories is indicated by colour (colour/height scale in the lower left corner of the plot). Each 3-hour interval along the trajectory path is indicated by a small legend and each 24-hour interval by a big legend.

To identify possible events of regional transport, hotspot/ fire the location of a thermal anomaly was detected by MODIS using data from the middle infrared and thermal infrared bands [32]. Each MODIS sensor achieves global coverage once per day and once per night every $24 \mathrm{~h}$. Therefore, most fires detectable at a $1 \mathrm{~km}$ spatial resolution have the potential to have their FRP (Fire Radiative Power) measured four times a day. Figure 2 shows the locations of the active fires identified from MODIS observations during study events over the area of our interest. The MODIS monthly fire maps, available since 2001, showed that these events of biomass burning in March-April occurred annually. However, the duration, geographical extent, and emission of the smoke from these fires differ year by year.

The AErosol RObotic NETwork (AERONET) is a ground-based network of Cimel sun photometer that measures the extinction aerosol optical depth at 7 wavelengths $\lambda(340,380,440,500,670,870$, and $1020 \mathrm{~nm})$ from the direct sun measurements over locations. The AOD measurements are accurate to within \pm 0.01 . The size distribution of aerosols can be estimated from spectral AOD (typically 440$870 \mathrm{~nm}$ ). The negative slope of AOT with the wavelength on a logarithmic scale is known as the Angström parameter $(\alpha)$. This parameter (1) can be calculated from two or more wavelengths using the least squares fit. Values of $\alpha>2.0$ indicate that fine mode particles exist (e.g., smoke particles and sulphates), while values of $\alpha$ near zero indicate the presence of coarse mode particles such as desert dust [33]:

$$
\alpha=-\frac{d \ln _{\tau_{a}}}{d \ln \lambda}=-\frac{\ln \left(\tau_{a 2} / \tau_{a 1}\right)}{\ln \left(\lambda_{2} / \lambda_{1}\right)},
$$

where $\alpha$ is the wavelength exponent depending on the ratio of the particle coarse mode to the accumulation (small) one (Angström parameter), $\tau_{a}$ is the AOD and $\lambda$ is the wavelength.

The Navy Aerosol Analysis and Prediction System (NAAPS) model results were used to determine the distribution of aerosols from fires and volcanoes (model description and results are available from the web pages of the Naval Research Laboratory, Monterey, CA, USA; http://www.nrlmry.navy.mil/aerosol/). The NAAPS model 


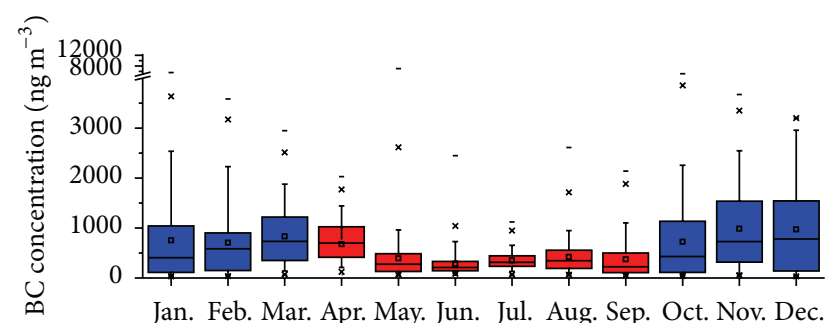

(a)

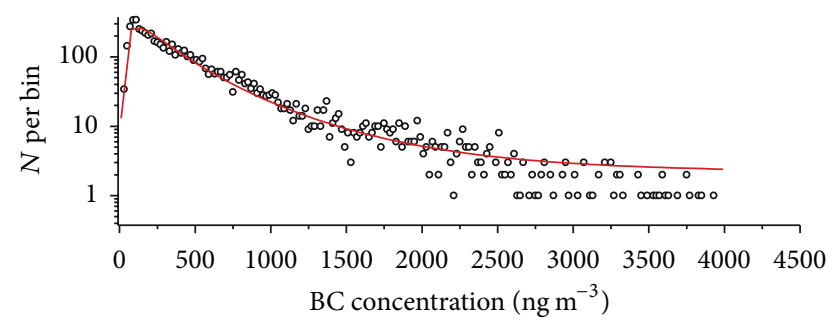

Data: black carbon

Model: $\log$ normal

Equation:

$y=y 0+A /\left(\sqrt{(2 * \mathrm{PI}) * w * x)} * \exp \left(-(\ln (x / x c))^{2} /\left(2 * w^{2}\right)\right)\right.$

$\chi^{2} / D \circ F=162.8$

$R^{2}=0.9$

y0: $2.1 \pm 1.2$

$x c: 284.5 \pm 9.0$

$w: 0.9 \pm 0.02$

A: $114749.7 \pm 2247.7$

(b)

FIGURE 1: (a) Box and whisker plots for comparison of mass concentrations at Preila; (b) BC concentration frequency distribution.

has been modified to incorporate real-time observations of biomass burning based on the joint Navy/NASA/NOAA Fire Locating and Modeling of Burning Emissions system (FLAMBE, http://www.nrlmry.navy.mil/aerosol/) [34]. The method has proven to be helpful in previous studies of longrange and regional transport of smoke [35].

\subsection{Black Carbon and Aerosol Particle Size Distribution} Measurements. A Magee Scientific Company Aethalometer, Model AE31 Spectrum, manufactured by Optotek, Slovenia, was deployed at the Vilnius site and provided real-time, continuous measurements of the BC mass concentrations. The optical transmission of carbonaceous aerosol particles was measured sequentially at seven wavelengths $\lambda(370,450,520$, $590,660,880$, and $950 \mathrm{~nm}$ ). The $880 \mathrm{~nm}$ is considered as the standard channel for BC measurements as at this wavelength $\mathrm{BC}$ is the principal absorber of light. The Aethalometer output is calculated directly as the $\mathrm{BC}$ concentrations through an internal conversion use assumed mass absorption efficiency. The Aethalometer converts light attenuation to the $\mathrm{BC}$ mass using a fixed specific attenuation cross-section $(\sigma)$ of $16.6 \mathrm{~m}^{2} \mathrm{~g}^{-1}$ of BC (Aethalometer Operations manual, Magee Scientific) [36].

This is the default value set by the manufacturer for a wavelength of $880 \mathrm{~nm}$. The Aethalometer data recorded with a 5-minute time base were compensated for loading effects using an empirical algorithm [36]. The Aethalometer was equipped with an additional impactor removing the particles larger than $2.5 \mu \mathrm{m}$ of the particle aerodynamic diameter. The starting time referred in this paper is Greenwich Mean Time (for local time: GMT +2:00).

The absorption coefficient $b_{\mathrm{abs}}$ for airborne particles is defined with Lambert-Beer's law as follows:

$$
I=I_{0} e^{\left(-b_{\mathrm{abs}} x\right)},
$$

where $I_{0}$ is the intensity of the incoming light and $I$ is the remaining light intensity after passing through a medium with thickness $x$.

A power law fit is commonly applied to describe the wavelength dependence of aerosol absorption coefficient $b_{\mathrm{abs}}$ :

$$
b_{\mathrm{abs}} \propto \lambda^{-\alpha}
$$

where $\lambda$ is the wavelength and $\alpha$ is the usually called Angström exponent of the absorption coefficient and is computed by fitting an exponential curve [37].

The aerosol size distribution was measured by using the Scanning Mobility Particle Sizer (SMPS) built by the Leibniz Institute for Tropospheric Research, Germany. The SMPS is composed of a differential mobility analyzer and CPC UF02proto. This system had the following general specifications: size range: $8-900 \mathrm{~nm}$; scan time: $5 \mathrm{~min}$; resolution: 71 size channels.

\section{Results}

In general, BC particles are mainly produced by anthropogenic activities such as fossil fuel burning (industries and transport) and biomass burning (agriculture or wildfires). However, the natural sources such as wildfires and volcanic eruptions also contribute to the $\mathrm{BC}$ mass concentration, but their contributions are relatively much less. We focused on the strongest periods of wildfire and volcanic events. The first event occurred on April 24-30, 2011 and the second on May 25-27, 2011. The concentrations observed during both events are clear outliers in their respective series, both for hourly concentrations and $24 \mathrm{~h}$ means.

3.1. Annual Variations of Aerosol Black Carbon. Box and whisker plots of BC concentrations and mass concentration frequency distribution are shown in Figures 1(a) and 1(b). The range of the box depicts the bounds of the 25th and the 75th percentiles of the data. The whiskers extending from the box represent the bounds of the 10th and the 90th percentiles.

The median and outliers of each dataset are also shown. It can be clearly seen that higher concentrations of $\mathrm{BC}$ are observed during October to March, when cold weather conditions prevail during any year.

The concentration shows a decrease in June $(280 \pm 230 \mathrm{ng}$ $\mathrm{m}^{-3}$ ), with the monthly mean $\mathrm{BC}$ concentration falling to more than half the value that prevailed in cold months. This low value is maintained until September. During this period no influence of residential heating was observed at the site. The mean $\mathrm{BC}$ concentration during this period is 


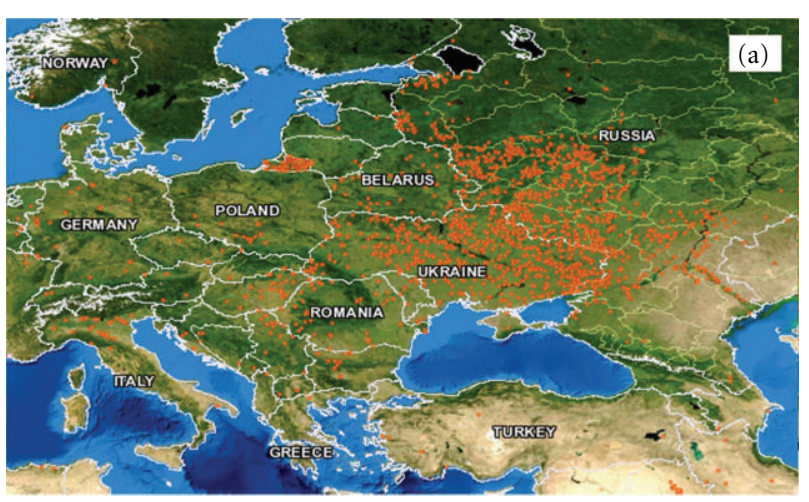

(a)

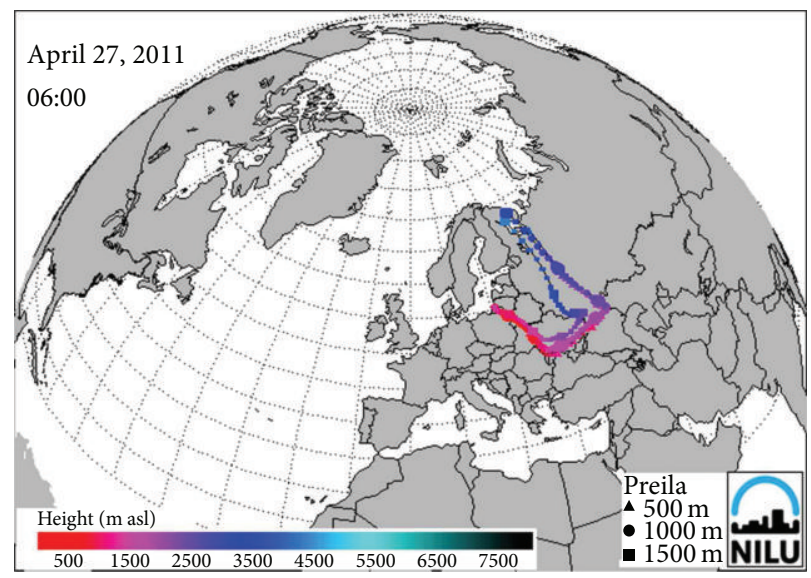

(c)
Smoke surface concentration $\left(\right.$ ug m $^{-3}$ ) for 18:00 April 26, 2011

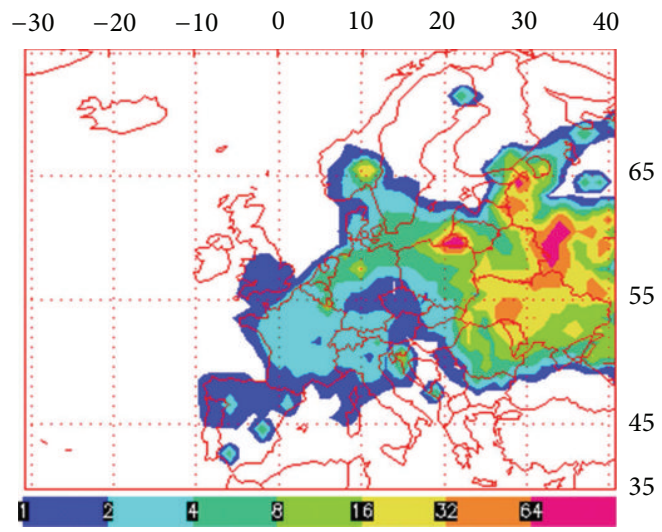

(b)

20110427 12:00

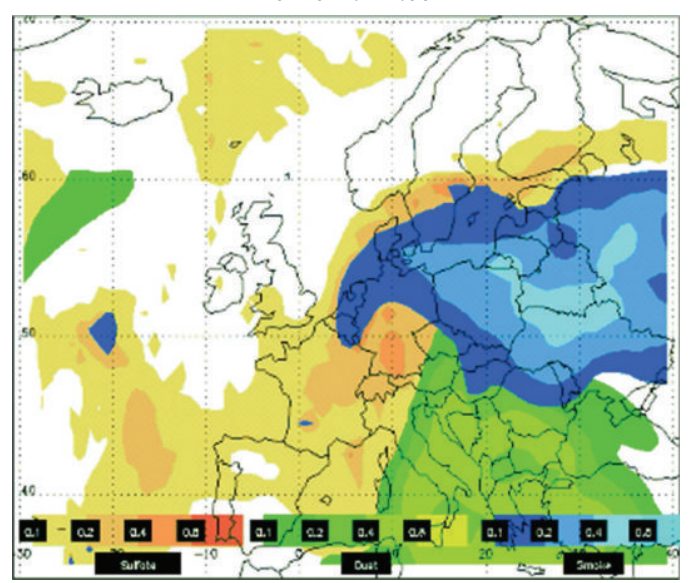

(d)

Figure 2: Active fires detected during April 24-30, 2011 during high BC concentration event: (a) by the MODIS Rapid Response System, ((b), (d)) sulphate, dust, and smoke surface concentration $\left(\mu \mathrm{g} \mathrm{m}^{-3}\right)$ for 18:00 April 262011 , and (c) 7-day air mass backward trajectories to Preila (at 500, 1000, and $1500 \mathrm{~m} \mathrm{AGL)} \mathrm{during} \mathrm{the} \mathrm{event} \mathrm{of} \mathrm{grass} \mathrm{fires.}$

$370 \pm 300 \mathrm{ng} \mathrm{m}^{-3}$ in contrast to the value of $750 \pm 550 \mathrm{ng} \mathrm{m}^{-3}$ during cold months (in blue).

Taking $25 \mathrm{ng} \mathrm{m}^{-3}$ value as frequency statistics step, the frequency distribution map of hourly average concentration of BC aerosol is depicted in Figure 1(b). The frequency distribution of hourly average $\mathrm{BC}$ aerosol does not have normal characterization. Using the log-normal distribution function to fit the frequency distribution characteristics, results show that approximately $70 \%$ of the measurements hourly average concentrations of $\mathrm{BC}$ aerosols were found in a mode in a low range of concentrations centered at approximately $200 \mathrm{ng} \mathrm{m}^{-3}$ indicating a direct impact of local emissions from combustion activities at the station. Mean BC mass concentrations ( $580 \mathrm{ng} \mathrm{m}^{-3}$ ) observed at Preila in 2011 are relatively low, comparable to that measured at the remote location. Comparing with the values reported from elsewhere for rural sites, mean $\mathrm{BC}$ values at Preila are comparable to that reported for Zappoli et al. [38] detected BC concentrations of $600 \mathrm{ngm}^{-3}$ at a background site in Hungary (K-Puszta).

\subsection{Spectroscopic Properties of Carbonaceous Aerosol}

3.2.1. April 24-30, 2011 Event. Fire Mapper products have provided data about the location and extent of fires during theevent days (Figure 2). Satellite images and model forecasts from NAAPS (Figures 2(b), 2(d)) for the study period suggested substantial emissions and LRT of smoke from the large fires burning in the southern part of Ukraine and Kaliningrad at that time.

Grass burning products were redistributed over Lithuania by the large-scale and regional atmospheric circulation. The air mass backward trajectory analysis showed that particles from BB with air masses in 3 days were brought to Lithuania and caused high peaks of aerosol number and BC concentrations. $\mathrm{BC}$ and aerosol number concentrations rose to higher levels over the whole territory of Lithuania. During this event the 1-hour average aerosol particle number concentration reached $4000 \mathrm{~cm}^{-3}, \mathrm{BC}-3500 \mathrm{ng} \mathrm{m}^{-3}$, while normally average concentration values are about $3100 \mathrm{~cm}^{-3}$ and $580 \mathrm{ng} \mathrm{m}^{-3}$, 


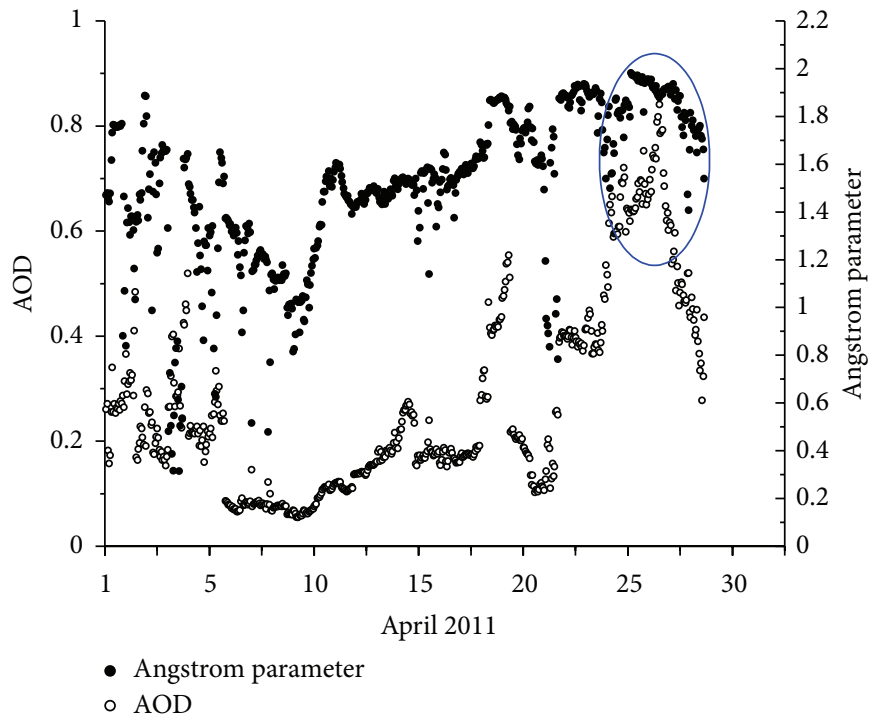

(a)

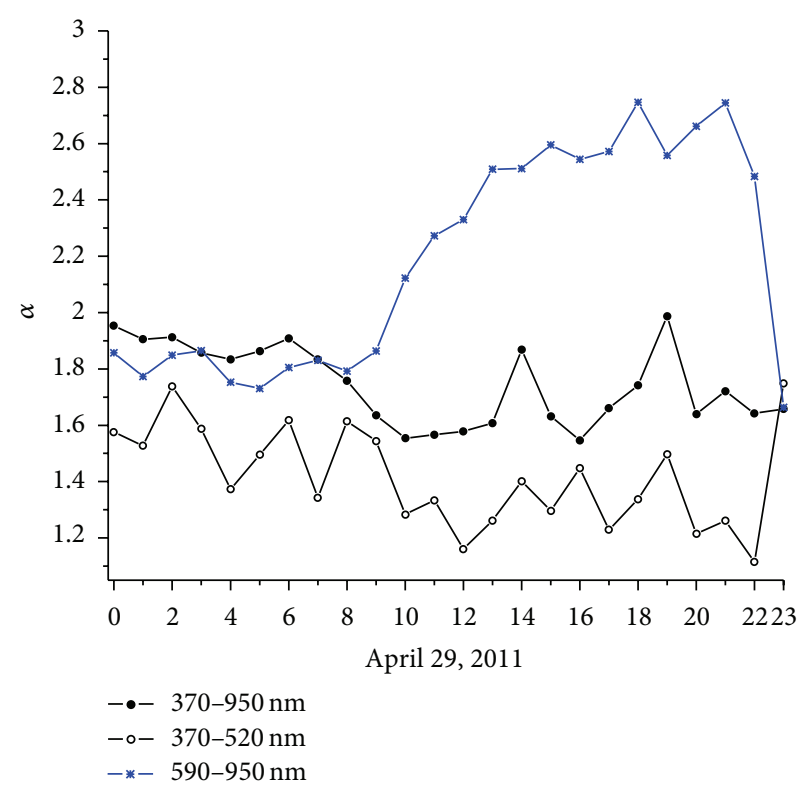

(b)

FIGURE 3: (a) The spectral variation of instantaneous measurements of AOD for April 2011 showing the gradual buildup and decline of smoke concentrations in this period (April 25-29, blue cycle); (b) values of the Angström exponent of the absorption coefficient (April 29, 2011) showing dynamic variations as a result of both increasing (decreasing) AOD and BC concentration and greater domination of fine mode versus coarse mode optical depth.

respectively. It should be noted that during April 24-30, 2011, urban sites belonging to the Lithuanian Automatic Urban Network (EPA) (http://stoteles.gamta.lt/) experienced peaks of $\mathrm{PM}_{10}$ concentration which coincided with extensive wildfires in Ukraine exceeding the European limit value 1.5 times.

Data analysis of the BC combined with TERRA/Moderate Resolution Imaging Spectroradiometer MODIS fire detections (Figure 2(a)) and NAAPS aerosol optical depth provided some insight into the aerosol regional transport of smoke. As shown in Figure 2(a), the MODIS clearly illustrates the fire location. The model forecasts from NAAPS for this period suggested substantial emissions and regional transport of smoke (Figure 2(c)) from the large fires burning in Kaliningrad and Ukraine regions at that time. During the study the NAAPS model predicted the optical depth of 0.6 at a wavelength of 0.55 microns for three components: sulfate and smoke over Europe due to smoke from the wildfires (Figure 2(d)). On the same days substantial concentrations of $\mathrm{BC}$ were observed during the period after air masses arrived from the fire location.

During the air mass transport to Lithuania, aerosol optical properties changed due to both deposition and mixing with local aerosols. The similar events were detected and studied by lidar networks covering the whole continent [39, 40] and also by a single lidar station [41]. Smoke plume was detected by the lidar and sun-photometric stations in Minsk, Belarus, Poland, and Belsk [42]. Belsk site is a joint AERONET site and it was possible to characterize the optical properties of aerosol particles at this site during our case study. From the first general overview of the field data, April
BB event can be recognized. In this study, the values of the Angström parameter were computed in the wavelength interval of $440-870 \mathrm{~nm}$, using the AOD data of the selected AERONET Belsk site, applying the least-squares method. AERONET profiles of the absorption Angström parameter (indicator of the AOD spectral dependence and related to particle size predominance) and AOD values at $500 \mathrm{~nm}$ obtained from MODIS for a period between April 1 and 30, 2011 are presented in Figure 3(a). The AOD measured in Belsk reached $0.90 \pm 0.02$ (these results are based on the AERONET cloud-screened and quality-assured data (level 2.0)). It can be seen that the Angström parameter values are mostly in the 1.4-2.0 range suggesting the presence of species that absorb more strongly at shorter wavelengths than black carbon, which might be associated with organics from biomass burning [43]. It is known that typical values of the Angström parameter range $\sim 2$ for fresh smoke particles (accumulation mode) to $\sim 0$ for coarse mode particles [33].

The wavelength dependence of the light absorption can be better approximated by separate exponential fits of the shorter $(370-520 \mathrm{~nm})$ and longer $(660-950 \mathrm{~nm})$ wavelengths obtained by an exponential curve fit over all 7 wavelengths. The Angstrom exponents were calculated by fitting $b_{\mathrm{abs}}$ for the whole available wavelength intervals: the short $(370-520 \mathrm{~nm})$ and long (590-950 nm) wavelength intervals (Figure 3(b)).

On the event day (April 29) the mean $\alpha$ values were significantly larger for the longer wavelengths $\left(\alpha_{590-960}=\right.$ $2.2 \pm 0.1)$ compared to the shorter wavelengths $\left(\alpha_{370-520}=\right.$ $1.4 \pm 0.1)$. During the event day the highest values of $\alpha_{590-960}$ were observed between $11 \mathrm{AM}$ and $11 \mathrm{PM}(2.7 \pm$ $0.1)$ while the highest values of $\alpha_{370-520}$ were observed 
between midnight and morning $(1.7 \pm 0.1)$. On nonevent days, the light absorption coefficients $\alpha_{370-950}, \alpha_{370-520}$, and $\alpha_{660-950} \mathrm{~nm}$ were within a narrow range of 1.2 , with weak diurnal cycles. For example, $\alpha$ value up to 1.5 was observed at a high Alpine station during a Saharan dust event [44].

Kirchstetter et al. [45] reported $\alpha$ value of 2.2 for outdoor firewood burning, 1.8 for a savanna fire, and $0.8-1.1$ for traffic-dominated sites (measurements with six wavelengths between 370 and $850 \mathrm{~nm}$ ). Schnaiter et al. [46, 47] reported $\alpha$ value of 1.1 for uncoated diesel soot (measurements with $\lambda=$ 450, 550, and $700 \mathrm{~nm}$ ). Previous investigations showed that the type of wood being burned also influenced the $\alpha$ value as shown by Day et al. [48] where they measured fresh wood smoke from seven types of forest wood with an Aethalometer $(\lambda=370-950 \mathrm{~nm})$ and reported $\alpha$ values between 0.9 and 2.2. Hoffer et al. [49] calculated $\alpha=6-7$ for water-soluble humiclike substances (HULIS) isolated from the fine fraction of the biomass burning aerosol spectrophotometer measurement with $\lambda=300-700 \mathrm{~nm}$ ).

These very high values of the absorption exponent are indicative of biomass combustion [37] in our case-wildfires as indicated by the air mass backward trajectory analysis (Figure 1) $[50,51]$. Though the increase in BC concentration associated with the BB event was instantaneous, the gradual decay after some days instantly recovered the BC concentration to the preevent level despite the fact of long atmospheric lifetime of BC. Reddy and Venkataraman [52] have found an annual average value of $\sim 6.5 \pm 4.8$ days for the BC lifetime. Globally, the average lifetime of $\mathrm{BC}$ is about 8 days.

The observed variations in the Angström exponent at 590-950 nm derived from the BC measurements are not consistent with AERONET Angström parameter (Figures 3(a), 3(b)). These comparisons show that there are differences between these two techniques for obtaining column average aerosol optical properties. Every aerosol technique has its advantages and disadvantages. Some are inherent in the instrument design or measurement type (e.g., sun photometers cannot measure valid AOD during cloudy periods).

3.2.2. May 24-27, 2011 Event. Figure 4 shows the air mass arriving at Preila at 12:00 (02 GMT) on May 24-27, 2011. As illustrated in Figure 4, the air mass came from the northeast, passing over Grimsvötn from which it was two-three days before arrival at the site. Results confirm that the volcanic plume arrived during the night between May 25 and May 26, 2011 after $72 \mathrm{~h}$ of transportation. The arrival elevation of $500 \mathrm{~m}$ a.g.l. locates within the inversion layer so that it is representative of the air sampled at Preila.

The sulphate concentration in the air was used as an indicator of volcanic pollution as sulphur dioxide is the third most abundant gas in volcanic emissions, after water vapor and carbon dioxide [53]. One week after the eruption the $\mathrm{SO}_{2}$ cloud reached Europe, where it was detected by groundbased instruments. At the Preila station, the plume was first detected on May 24-25 as $\mathrm{SO}_{2}$ concentrations peaked until reaching a maximum value of $1.36 \mathrm{mg} \mathrm{m}^{-3}$ and made up $14 \%$ of submicron aerosol particles [20]. The advection of volcanic plumes from Grimsvötn was also confirmed using the satellite images. For the UV/visible instrument GOME-2 the Differential Optical Absorption Spectroscopy was used. After the eruption, the plume drifted to the southeast where it formed a distinct loop due to atmospheric winds. GOME2 measured $\mathrm{SO}_{2}$ column amounts on May 29, of $>10 \mathrm{DU}$ after 8 days after the eruption (http://sacs.aeronomie.be/). Time variations of sulphate AOD observed during May 17-31, 2011 showed that the AOD values were significantly larger on May 28-29, whereas extremely low sulphate concentrations prevailed during the period from 25 to 26 May. Thus, we conclude that the high values of sulphate AOD measurments measured during the first half of the observation period after eruption were caused by the volcanic plumes transported from Grimsvötn.

A carbonaceous aerosol component has been observed in fresh volcanic clouds from several volcanoes [11]. The Angström exponent of the absorption coefficient for organic species depends on the wavelength. Studies show $\alpha$ value for organic species is larger than for black carbon [45], whereas it is less dependent on the wavelength for BC. The dependence of $\alpha$ on the wavelength can be seen in Figure 5 for the study case.

Figure 5 shows time series for the hourly mean values of $\alpha$ from May 24 to May 28, 2011. Since at the UV wavelength there could be some organic compound strongly absorbing, thus leading to an overestimation of the $\alpha$ parameter, the wavelength range $370-950 \mathrm{~nm}$ has been considered for the best-fit technique application and $\alpha$ parameter estimation. The fact that $\alpha_{370-550}$ becomes higher than $\alpha_{590-950}$ shows that the influence of the organic aerosols exists, but its influence is limited, probably connected to changes in variations in the composition of air masses crossing the Preila site. BC concentration maximum values (at $880 \mathrm{~nm}$ ), depending on the day, were varying between 150 and $1200 \mathrm{ng} \mathrm{m}^{-3}$. In Preila, mean $\alpha_{370-550}$ values (Figure 5) collected in May 25-26, 2011 have been found to be $\sim 1.9 \pm 0.5$ while measurements collected during May 24 and 27-28, 2011 give mean alpha value $\sim 1.5 \pm 0.5$. Hence, it can be concluded that low BC contributed mainly to the light absorption, which is well consistent with an average $\alpha_{370-550}$ and $\alpha_{590-950}$ close to 1.5 and 1.8, respectively. Explanation of the carbon content of the air other than direct volcanic emissions needs to be considered [54].

Parallel to the measurement of $\alpha$, the aerosol absorption coefficient $b_{\text {abs }}(\lambda)$ was evaluated (Figure 6 ). The spectral dependence allows distinguishing carbonaceous aerosols from different sources because of light absorbing $\mathrm{OC}$ which in contrast to $\mathrm{BC}$ exhibits a stronger absorption at shorter wavelengths [43]. In the period during the volcanic activity the value of $\alpha_{370-550}$ was slightly lower $(1.3 \pm 0.3)$ than that of $\alpha_{590-950}(1.4 \pm 0.2)$ and was contrary to the value after air masses passed the Preila site, that is, $\alpha_{370-550}$ and $\alpha_{590-950} \mathrm{~nm}$ of $2.1 \pm 0.4$ and $2.4 \pm 0.4$, respectively. This is a strong suggestion that the aerosol includes less absorbers of the shorter wavelengths during the volcanic event. According to values of the Angström exponent of the absorption coefficients $\alpha_{370-550}$ and $\alpha_{590-950} \mathrm{~nm}$ along with the air mass backward trajectories calculation, we can assume that the decrease in the organic carbon concentration was caused by the volcano at Grimsvötn in Iceland. 


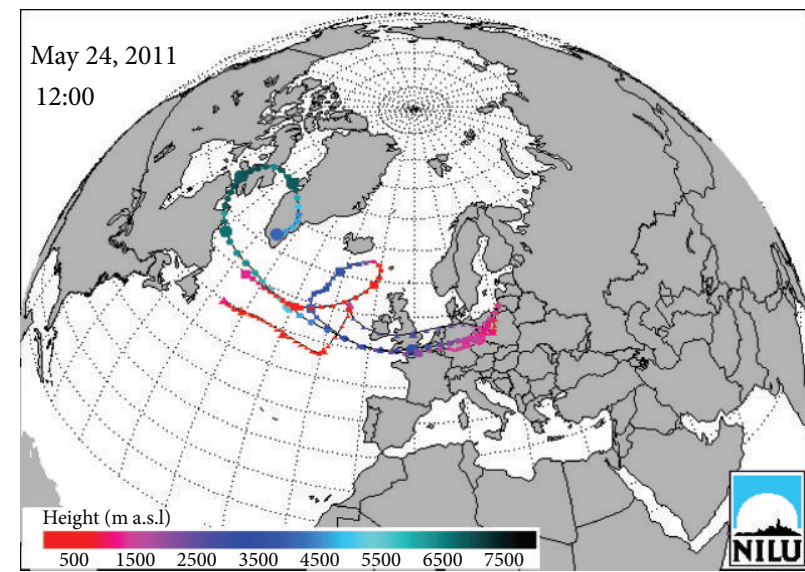

(a)

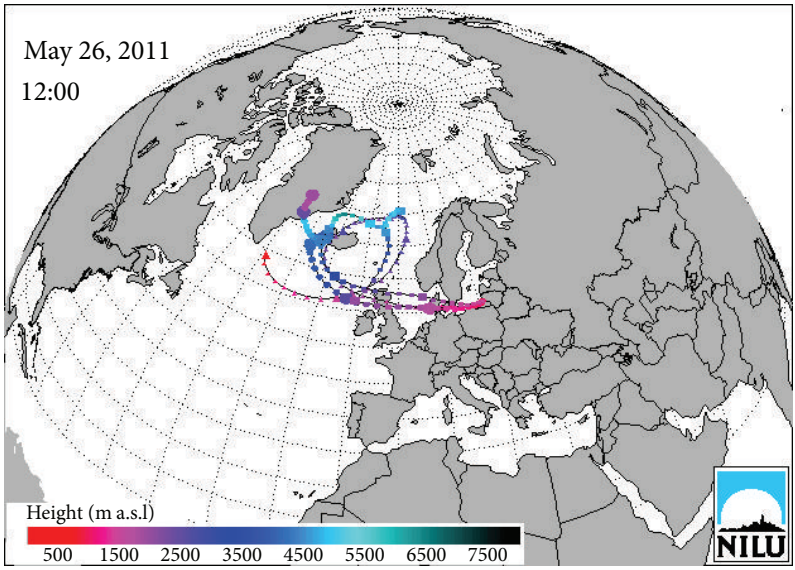

Preila

- $500 \mathrm{~m}$

- $1000 \mathrm{~m}$

- $1500 \mathrm{~m}$

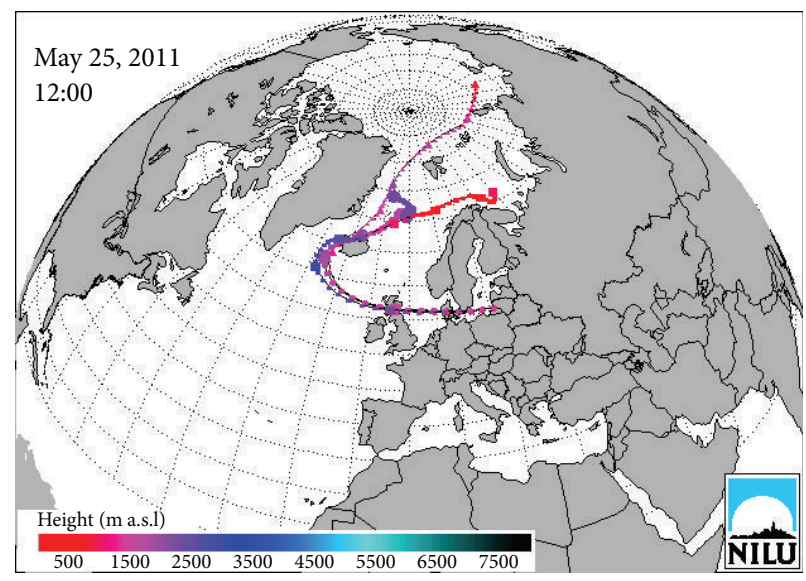

(b)

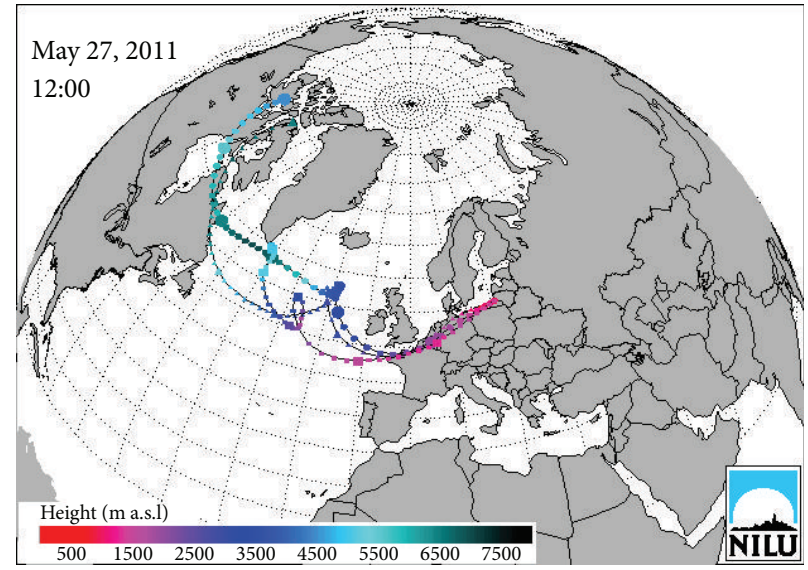

Preila

- $500 \mathrm{~m}$

- $1000 \mathrm{~m}$

- $1500 \mathrm{~m}$

(c)

(d)

FIGURE 4: Backward trajectories of the air masses from the volcano at Grimsvötn to Lithuania on 24-27 ((a)-(d)) May 2011 (12:00 UTC).

It is to be noted that the Angstrom exponent could be a rough indicator of the size distribution of the aerosol particles whereas the Angström exponent of the absorption coefficient tells about the nature of absorbing aerosols. A low $\alpha$ value $(<1)$ indicates dominance of larger-size particles and a high $\alpha$ $(>1)$ indicates dominance of smaller-size particles [55]. This assumption was also confirmed in the study by Kvietkus et al. [20], when the particulate organic matter concentrations of $\mathrm{PM}_{1}$ were lower during the period of the volcanic eruption, but an increase in sulfate concentration from 1.13 to $3.86 \mu \mathrm{g} \mathrm{m}^{-3}\left(90 \%\right.$ of $\left.\mathrm{PM}_{1}\right)$ on May 25 , in the Vilnius area was observed. Baker et al. [56] showed that in the volcanic cloud of Grimsvötn chlorine radicals rapidly depleted organic trace gases to levels well below background concentrations. This process could increase particulate carbon amount in the volcanic cloud. This could explain the increase in BC concentration in May 27 and parallel decrease in organic fraction (Figure 5).
Volcanic particles are assumed to be composed of ash particles and hygroscopic sulfates. Volcanic particles are injected in the atmosphere both as primary particles rapidly deposited due to their large sizes on time scales of minutes to a few weeks in the troposphere and as secondary particles mainly derived from the oxidation of sulphur dioxide [57]. For a detailed analysis of the event the diurnal pattern of the time dependent size distribution for Preila during May 24, 2011 is depicted in Figure 7. New particle formation events were found on 4 days (May 24-27). We will focus here on the event that we observed at the Preila station on May 24, 2011. In the morning of these days, air masses arrived to Preila from the Baltic Sea area when higher altitude (above 2000-3500 $\mathrm{m}$ a.s.1.) air masses continued to arrive straight from the Grimsvötn, the lower level (below $500 \mathrm{~m}$ a.s.l.). The aerosol also shows a high concentration of $\mathrm{SO}_{2}$ during the experiment when air masses came from the volcano accompanied with high sulphur $\left(45.2 \mu \mathrm{g} \mathrm{m}^{-3}\right)$. 


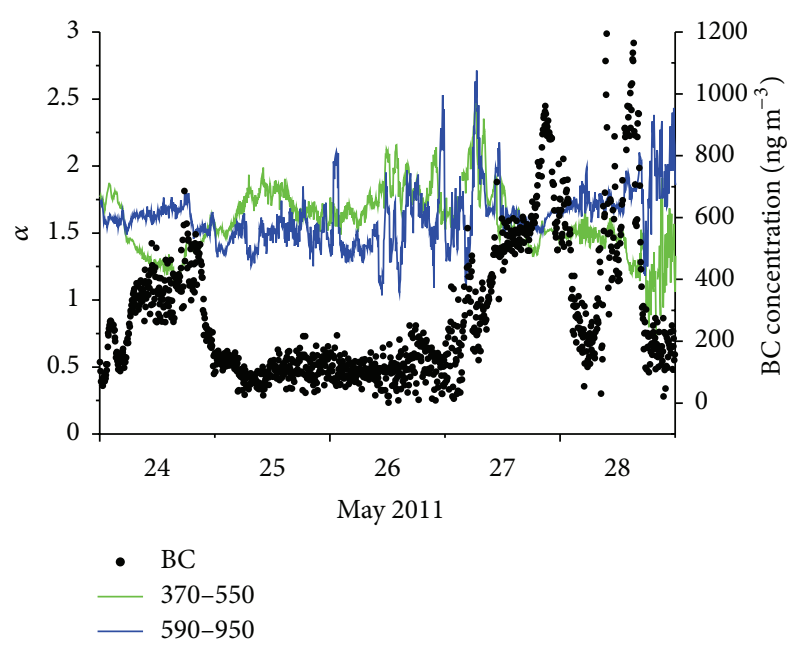

Figure 5: Time series of the hourly mean Angström exponent of the absorption coefficient on May 24-28, 2011.

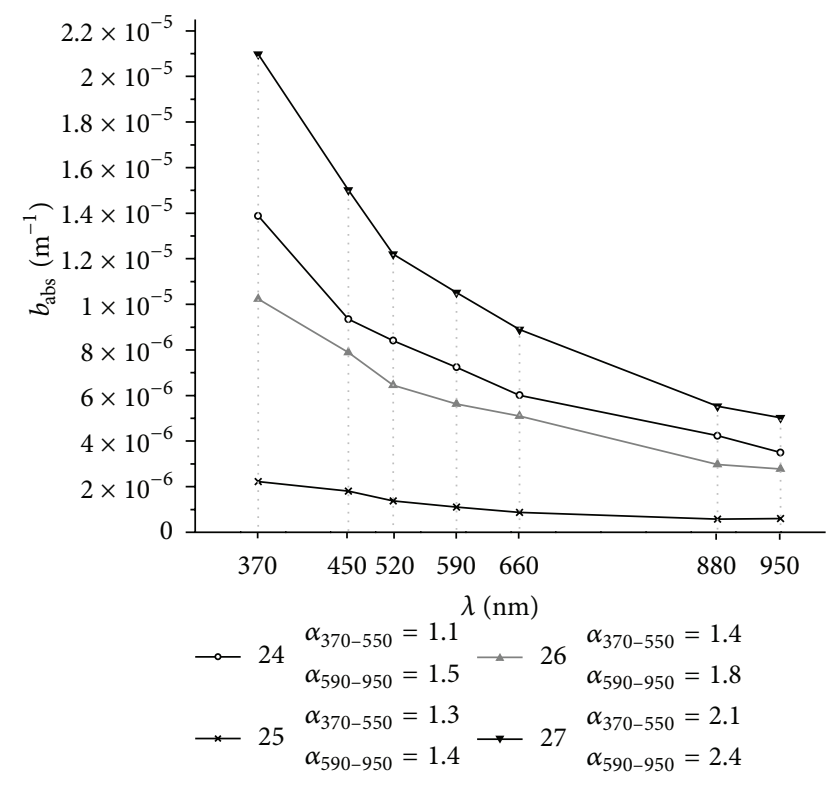

Figure 6: The light Angström exponent of the absorption coefficients $\alpha_{370-520}$ and $\alpha_{590-950} \mathrm{~nm}$ during May 24-27, 2011.

A very strong source of $\mathrm{SO}_{2}$ located in the southern maritime area is suspected to have caused these extraordinary high $\mathrm{SO}_{2}$ concentrations. As the sun is rising, photochemical reactions lead gas phase $\mathrm{SO}_{2}$ to be oxidized to sulfuric acid.

As shown in Figure 7, the nigh ttime 00:00-07:00 AM was associated with higher number concentration of accumulation mode particles $\left(D_{p} \sim 100 \mathrm{~nm}\right)$. During new particle formation events, the nucleation mode particles showed an obvious one-peak diurnal variation: the number concentration was very low in the early morning, started to increase abruptly at about 9:00 in the morning, and reached its maximum to a value of $30,000 \mathrm{~cm}^{-3}$. On the contrary the concentration of Aitken mode particles remained low between 00:00 and 9:00 A.M. After this point, the formation

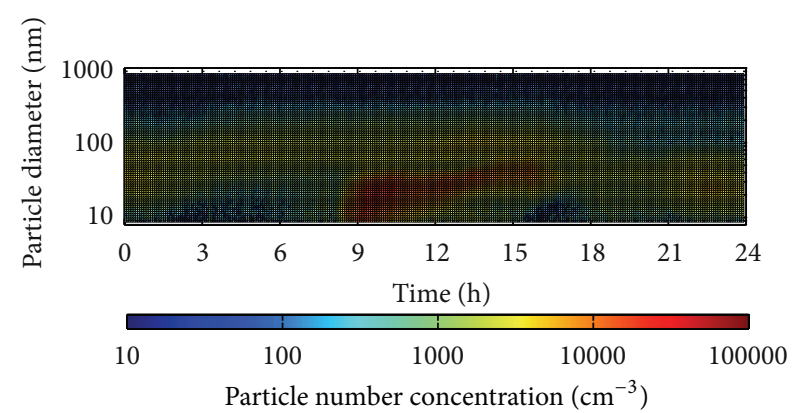

(a)

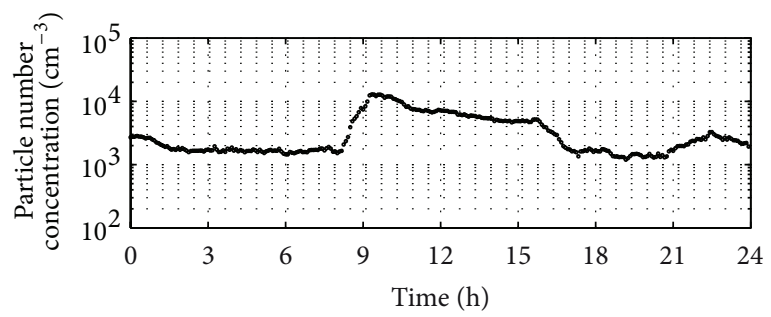

(b)

FIGURE 7: Contour plot of new particle formation and growth on 24 May 2011; colour represents logarithm of concentration in $\mathrm{cm}^{-3}$.

TABLE 1: The growth rate of new particles.

\begin{tabular}{lcccc}
\hline & \multicolumn{4}{c}{ Date } \\
& 24 May & 25 May & 26 May & 27 May \\
\hline Growth rate, $\mathrm{nm} \mathrm{h}^{-1}$ & 5.36 & 2.55 & 5.58 & 25.20 \\
\hline
\end{tabular}

of new particles started and the concentration of nucleation mode particles increased. Later the number of concentrations reached its lowest level from 6:00 P.M. till the next morning. The growth rates (Table 1) of new particles were calculated using the method described by Kulmala et al. [58].

The growth rates were in the range of $2.55-25.20 \mathrm{~nm} \mathrm{~h}^{-1}$; the growth rates are in the range of typical observed particle growth rates $\left(1-20 \mathrm{~nm} \mathrm{~h}^{-1}\right)$ [59].

\section{Conclusions}

A combination of ground-based and satellite observations was used in this study to investigate different sources of aerosol BC loadings over Lithuania during two different time periods, April 24-30 and May 24-2, 2011. The 7-wavelength setup of the Aethalometer has been exploited to obtain information on variation of spectroscopic properties of carbonaceous particles. Although BC mass concentration values do not allow one to a priori determine which process produces BC, the wavelength dependence of the BC absorption gives the option to follow the variation carbonaceous aerosol properties and easily characterize the black carbon/organic component.

Near-source biomass burning smoke is observed routinely in Lithuania, while volcanic effluent plumes provided some new information. During these periods the measured 
black carbon concentration during $\mathrm{BB}$ and volcanic activity events (3500 and $1200 \mathrm{ng} \mathrm{m}^{-3}$, resp.) exceeded previously established average values of $580 \mathrm{ng} \mathrm{m}^{-3}$. Compared to background aerosols, the sampled plumes have higher AOD and contain particles having expected differences in the Angstrom exponent and size. During the wildfire burning event on April 24-30 2011 the highest mean values of the Angström exponent of the absorption coefficients $\alpha_{370-520}$ and $\alpha_{590-950} \mathrm{~nm}$ were observed (1.4 \pm 0.1 and $2.2 \pm 0.1$, resp.), and during the volcanic event on May 25-27, 2011 the peak values were determined ( $1.3 \pm 0.3$ and $1.4 \pm 0.2$, resp.). This is a strong suggestion that the aerosol includes less absorbers of the shorter wavelengths during the volcanic event.

The observational data and analysis presented here demonstrate that nucleation and subsequent growth can be derived from volcanic eruption gaseous released and that this new secondary particle formation event could occur within the lower troposphere at a large distance from the eruptive activity.

\section{Acknowledgments}

This work was supported by the Lithuanian-Swiss Cooperation Programme "Research and Development" project AEROLIT (Nr. CH-3-ŠMM-01/08). The authors thank Piotr Sobolewski, Brent Holben, and Aleksander Pietruczuk and their staff for establishing and maintaining the Belsk site used in this investigation. The authors declare that they have no competing interests as defined by Advances in Meteorology or other interests that might be perceived to influence the results and discussion reported in this paper.

\section{References}

[1] M. L. Bell, J. M. Samet, and F. Dominici, "Time-series studies of particulate matter," Annual Review of Public Health, vol. 25, pp. 247-280, 2004.

[2] C. A. Pope and D. W. Dockery, "Health effects of fine particulate air pollution: lines that connect," Journal of the Air and Waste Management Association, vol. 56, no. 6, pp. 709-742, 2006.

[3] J. P. Schwarz, J. R. Spackman, D. W. Fahey et al., "Coatings and their enhancement of black carbon light absorption in the tropical atmosphere," Journal of Geophysical Research, vol. 113, no. 3, Article ID D03203, 2008.

[4] V. Ramanathan, F. Li, M. V. Ramana et al., "Atmospheric brown clouds: hemispherical and regional variations in longrange transport, absorption, and radiative forcing," Journal of Geophysical Research, vol. 112, no. 22, Article ID D22S21, 2007.

[5] P. J. Grutzen and M. O. Andreae, "Biomass burning in the tropics: impact on atmospheric chemistry and biogeochemical cycles," Science, vol. 250, no. 4988, pp. 1669-1678, 1990.

[6] P. G. Simmonds, A. J. Manning, R. G. Derwent et al., "A burning question: can recent growth rate anomalies in the greenhouse gases be attributed to large-scale biomass burning events?" Atmospheric Environment, vol. 39, no. 14, pp. 2513-2517, 2005.

[7] M. O. Andreae and P. Merlet, "Emission of trace gases and aerosols from biomass burning," Global Biogeochemical Cycles, vol. 15, no. 4, pp. 955-966, 2001.
[8] Y. J. Kaufman, D. Tanré, and O. Boucher, "A satellite view of aerosols in the climate system," Nature, vol. 419, pp. 215-223, 2002.

[9] H. Huntrieser, J. Heland, H. Schlager et al., "Intercontinental air pollution transport from North America to Europe: experimental evidence from airborne measurements and surface observations," Journal of Geophysical Research, vol. 110, no. 1, pp. $1-22,2005$.

[10] D. M. Murphy, D. S. Thomson, and M. J. Mahoney, "In situ measurements of organics, meteoritic material, mercury, and other elements in aerosols at 5 to 19 kilometers," Science, vol. 282, no. 5394, pp. 1664-1669, 1998.

[11] B. G. Martinsson, C. A. M. Brenninkmeijer, S. A. Cam et al., "Influence of the 2008 Kasatochi volcanic eruption on sulfurous and carbonaceous aerosol constituents in the lower stratosphere," Geophysical Research Letters, vol. 36, no. 12, Article ID L12813, 2009.

[12] S. S. Abdalmogith and R. M. Harrison, "The use of trajectory cluster analysis to examine the long-range transport of secondary inorganic aerosol in the UK," Atmospheric Environment, vol. 39, no. 35, pp. 6686-6695, 2005.

[13] “TF-HTAP. Hemispheric Transport of Air Pollution,” in Air Pollution Studies, no. 16, United Nations Economic Commission for Europe, New York, NY, USA and Geneva, Switzerland, 2007, http://www.htap.org/.

[14] J. F. Liu, D. L. Mauzerall, and L. W. Horowitz, "Source-receptor relationships of trans-pacific transport of East Asian sulfate," Atmospheric Chemistry and Physics, vol. 8, pp. 5537-5561, 2008.

[15] E. Saikawa, V. Naik, L. W. Horowitz, J. Liu, and D. L. Mauzerall, "Present and potential future contributions of sulfate, black and organic carbon aerosols from China to global air quality, premature mortality and radiative forcing," Atmospheric Environment, vol. 43, no. 17, pp. 2814-2822, 2009.

[16] R. Damoah, N. Spichtinger, C. Forster et al., "Around the world in 17 days-Hemispheric-scale transport of forest fire smoke from Russia in May 2003," Atmospheric Chemistry and Physics, vol. 4, no. 5, pp. 1311-1321, 2004.

[17] J. V. Niemi, H. Tervahattu, H. Vehkamäki et al., "Characterization and source identification of a fine particle episode in Finland," Atmospheric Environment, vol. 38, no. 30, pp. 50035012, 2004.

[18] D. Müller, I. Mattis, U. Wandinger, A. Ansmann, D. Althausen, and A. Stohl, "Raman lidar observations of aged Siberian and Canadian forest fire smoke in the free troposphere over Germany in 2003: microphysical particle characterization," Journal of Geophysical Research, vol. 110, no. 17, Article ID D17201, pp. 75-90, 2005.

[19] B. Langman, A. Folch, M. Hensch, and V. Matthias, "Volcanic ash over Europe during the eruption of Eyjafjallajökull on Iceland, April-May 2010," Atmospheric Environment, vol. 48, pp. $1-8,2012$.

[20] K. Kvietkus, J. Šakalys, J. Didžbalis, I. Garbariene, N. Špirkauskaite, and V. Remeikis, "Atmospheric aerosol episodes over Lithuania after the May 2011 volcano eruption at Grimsvötn, Iceland," Atmospheric Research, vol. 122, pp. 93-101, 2013.

[21] K. H. Lee, J. E. Kim, Y. J. Kim, J. Kim, and W. Von HoyningenHuene, "Impact of the smoke aerosol from Russian forest fires on the atmospheric environment over Korea during May 2003," Atmospheric Environment, vol. 39, no. 1, pp. 85-99, 2005.

[22] M. Sillanpää, R. Hillamo, S. Saarikoski et al., "Chemical composition and mass closure of particulate matter at six urban sites in 
Europe," Atmospheric Environment, vol. 40, no. 2, pp. 212-223, 2006.

[23] P. Anttila, U. Makkonen, H. Hellén et al., "Impact of the open biomass fires in spring and summer of 2006 on the chemical composition of background air in south-eastern Finland," Atmospheric Environment, vol. 42, no. 26, pp. 6472-6486, 2008.

[24] A. Karppinen, J. Härkönen, J. Kukkonen, P. Aarnio, and T. Koskentalo, "Statistical model for assessing the portion of fine particulate matter transported regionally and long range to urban air," Scandinavian Journal of Work, Environment and Health, vol. 30, no. 2, pp. 47-53, 2004.

[25] M. Sillanpää, A. Frey, R. Hillamo, A. S. Pennanen, and R. O. Salonen, "Organic, elemental and inorganic carbon in particulate matter of six urban environments in Europe," Atmospheric Chemistry and Physics, vol. 5, no. 11, pp. 2869-2879, 2005.

[26] J. Ovadnevaite, K. Kvietkus, and A. Maršalka, "2002 summer fires in Lithuania: impact on the Vilnius city air quality and the inhabitants health," Science of the Total Environment, vol. 356, no. 1-3, pp. 11-21, 2006.

[27] S. Saarikoski, M. Sillanpää, M. Sofiev et al., "Chemical composition of aerosols during a major biomass burning episode over northern Europe in spring 2006: experimental and modelling assessments," Atmospheric Environment, vol. 41, no. 17, pp. 35773589, 2007.

[28] V.-M. Kerminen, J. V. Niemi, H. Timonen et al., "Characterization of volcanic ash in southern Finland caused by the Grimsvötn eruption in May 2011," Atmospheric Chemistry and Physics, vol. 11, pp. 12227-12239, 2011.

[29] G. L. Schuster, O. Dubovik, and B. N. Holben, "Angstrom exponent and bimodal aerosol size distributions," Journal of Geophysical Research, vol. 111, no. 7, Article ID D07207, 2006.

[30] Y. J. Kaufman, A. Gitelson, A. Karnieli et al., "Size distribution and scattering phase function of aerosol particles retrieved from sky brightness measurements," Geophysical Research Letters, vol. 99, pp. 10341-10356, 1994.

[31] A. Stohl, G. Wotawa, P. Seibert, and H. Kromp-Kolb, "Interpolation errors in wind fields as a function of spatial and temporal resolution and their impact on different types of kinematic trajectories," Journal of Applied Meteorology, vol. 34, no. 10, pp. 2149-2165, 1995.

[32] L. Giglio, "Characterization of the tropical diurnal fire cycle using VIRS and MODIS observations," Remote Sensing of Environment, vol. 108, no. 4, pp. 407-421, 2007.

[33] T. F. Eck, B. N. Holben, J. S. Reid et al., "Wavelength dependence of the optical depth of biomass burning, urban, and desert dust aerosols," Journal of Geophysical Research, vol. 104, no. 24, pp. 31333-31349, 1999.

[34] J. S. Reid, E. M. Prins, D. L. Westphal et al., "Real-time monitoring of South American smoke particle emissions and transport using a coupled remote sensing/box-model approach," Geophysical Research Letters, vol. 31, no. 6, Article ID L06107, 5 pages, 2004.

[35] R. E. Honrath, R. C. Owen, M. Val Martín et al., "Regional and hemispheric impacts of anthropogenic and biomass burning emissions on summertime $\mathrm{CO}$ and $\mathrm{O}_{3}$ in the North Atlantic lower free troposphere," Journal of Geophysical Research, vol. 109, no. 24, pp. 1-17, 2004.

[36] A. Virkkula, T. Mäkelä, R. Hillamo et al., "A simple procedure for correcting loading effects of aethalometer data," Journal of the Air and Waste Management Association, vol. 57, no. 10, pp. 1214-1222, 2007.
[37] J. Sandradewi, A. S. H. Prévôt, E. Weingartner, R. Schmidhauser, M. Gysel, and U. Baltensperger, "A study of wood burning and traffic aerosols in an Alpine valley using a multiwavelength Aethalometer," Atmospheric Environment, vol. 42, no. 1, pp. 101-112, 2008.

[38] S. Zappoli, A. Andracchio, S. Fuzzi et al., "Inorganic, organic and macromolecular components of fine aerosol in different areas of Europe in relation to their water solubility," Atmospheric Environment, vol. 33, no. 17, pp. 2733-2743, 1999.

[39] A. Ansmann, J. Bösenberg, A. Chiakovsky et al., "Long-range transport of Saharan dust to northern Europe: the 11-16 October 2001 outbreak observed with EARLINET,' Journal of Geophysical Research, vol. 108, no. 24, pp. 1-15, 2003.

[40] J. G. Goldammer, "The wildland fire season 2002 in the Russian Federation: an assessment by the global fire monitoring centre (GFMC)," International Forest Fire News, vol. 28, pp. 2-14, 2003.

[41] A. E. Kardas, K. M. Markowicz, S. P. Malinowski et al., "SAWA experiment-properties of mineral dust aerosol as seen by synergic lidar and sun-photometer measurements," Atmospheric Chemistry and Physics Discussions, vol. 6, pp. 12155-12178, 2006.

[42] A. Pietruczuk and A. P. Chaikovsky, "Properties of fire smoke in Eastern Europe measured by remote sensing methods," in Remote Sensing of Clouds and the Atmosphere, vol. 6745 of Proceedings of SPIE, October 2007.

[43] H. Moosmüller, R. K. Chakrabarty, and W. P. Arnott, "Aerosol light absorption and its measurement: a review," Journal of Quantitative Spectroscopy and Radiative Transfer, vol. 110, pp. 844-878, 2009.

[44] M. Collaud-Coen, E. Weingartner, D. Schaub et al., "Saharan dust events at the Jungfraujoch: detection by wavelength dependence of the single scattering albedo and first climatology analysis," Atmospheric Chemistry and Physics, vol. 4, no. 11-12, pp. 2465-2480, 2004.

[45] T. W. Kirchstetter, T. Novakov, and P. V. Hobbs, "Evidence that the spectral dependence of light absorption by aerosols is affected by organic carbon," Journal of Geophysical Research, vol. 109, no. 21, Article ID D21208, 12 pages, 2004.

[46] M. Schnaiter, H. Horvath, O. Möhlter, K. H. Naumann, H. Saafhoff, and O. W. Schock, "UV-VIS-NIR spectral optical properties of soot and soot-containing aerosols," Journal of Aerosol Science, vol. 34, pp. 1421-1444, 2003.

[47] M. Schnaiter, C. Linke, O. Möhler et al., "Absorption amplification of black carbon internally mixed with secondary organic aerosol," Journal of Geophysical Research, vol. 110, no. 19, Article ID D19204, pp. 1-11, 2005.

[48] D. E. Day, J. L. Hand, C. M. Carrico, G. Engling, and W. C. Malm, "Humidification factors from laboratory studies of fresh smoke from biomass fuels," Journal of Geophysical Research, vol. 111, no. 22, Article ID D22202, 2006.

[49] A. Hoffer, A. Gelencsér, P. Guyon et al., "Optical properties of humic-like substances (HULIS) in biomass-burning aerosols," Atmospheric Chemistry and Physics, vol. 6, no. 11, pp. 3563-3570, 2006.

[50] V. Ulevicius, S. Byčenkienè, V. Remeikis et al., “Characterization of aerosol particle episodes in Lithuania caused by long-range and regional transport," Atmospheric Research, vol. 98, no. 2-4, pp. 190-200, 2010.

[51] V. Ulevičius, S. Byčenkiene, N. Špirkauskaite, and S. Kecorius, "Biomass burning impact on black carbon aerosol mass concentration at a coastal site: case studies," Lithuanian Journal of Physics, vol. 50, no. 3, pp. 335-344, 2010. 
[52] M. S. Reddy and C. Venkataraman, "Direct radiative forcing from anthropogenic carbonaceous aerosols over India," Current Science, vol. 76, no. 7, pp. 1005-1011, 1999.

[53] R. von Glasow, N. Bobrowski, and C. Kern, "The effects of volcanic eruptions on atmospheric chemistry," Chemical Geology, vol. 263, no. 1-4, pp. 131-142, 2009.

[54] S. M. Andersson, B. G. Martinsson, J. Friberg et al., "Composition and evolution of volcanic aerosol from eruptions of Kasatochi, Sarychev and Eyjafjallajökull in 2008-2010 based on CARIBIC observations during air space closure in April and May 2010," Atmospheric Chemistry and Physics, vol. 13, pp. 17811796, 2013.

[55] O. Dubovik, B. Holben, T. F. Eck et al., "Variability of absorption and optical properties of key aerosol types observed in worldwide locations," Journal of the Atmospheric Sciences, vol. 59, no. 3, pp. 590-608, 2002.

[56] A. K. Baker, A. Rauthe-Schöch, T. J. Schuck et al., "Investigation of chlorine radical chemistry in the Eyjafjallajökull volcanic plume using observed depletions in non-methane hydrocarbons," Geophysical Research Letters, vol. 38, Article ID L13801, 2011.

[57] U. Schumann, B. Weinzierl, O. Reitebuch et al., "Airborne observations of the Eyjafjalla volcano ash cloud over Europe during air space closure in April and May 2010," Atmospheric Chemistry and Physics Discussions, vol. 10, no. 9, pp. 2213122218, 2010.

[58] M. Kulmala, T. Petäjä, P. Mönkkönen et al., "On the growth nucleation mode particles: source rates of condensable vapor in polluted and clean environments," Atmospheric Chemistry and Physics, vol. 5, no. 2, pp. 409-416, 2005.

[59] M. Kulmala, H. Vehkamäki, T. Petäjä et al., "Formation and growth rates of ultrafine atmospheric particles: a review of observations," Journal of Aerosol Science, vol. 35, no. 2, pp. 143176, 2004. 

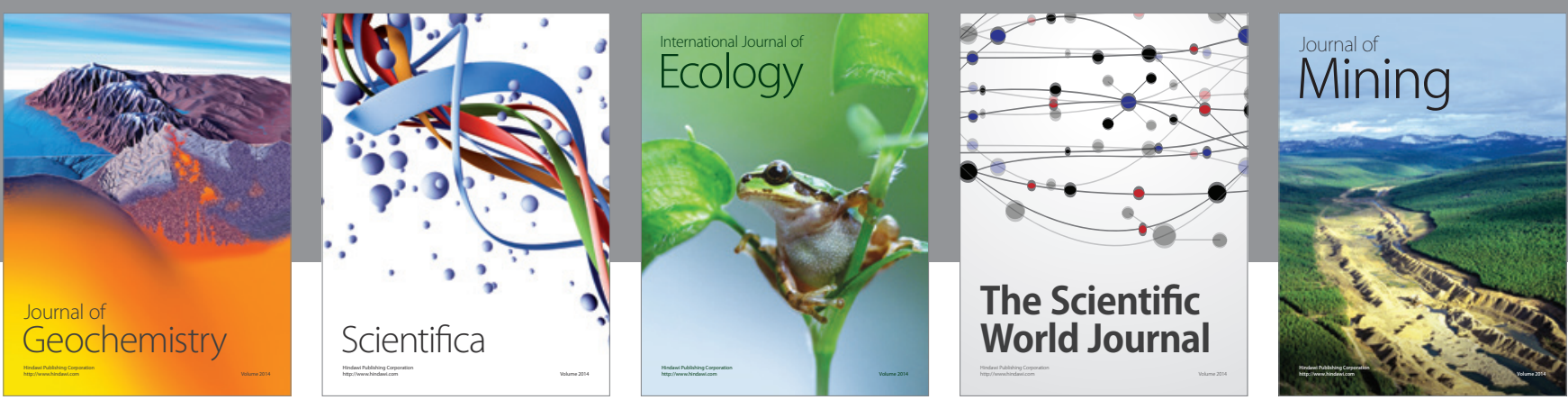

The Scientific World Journal
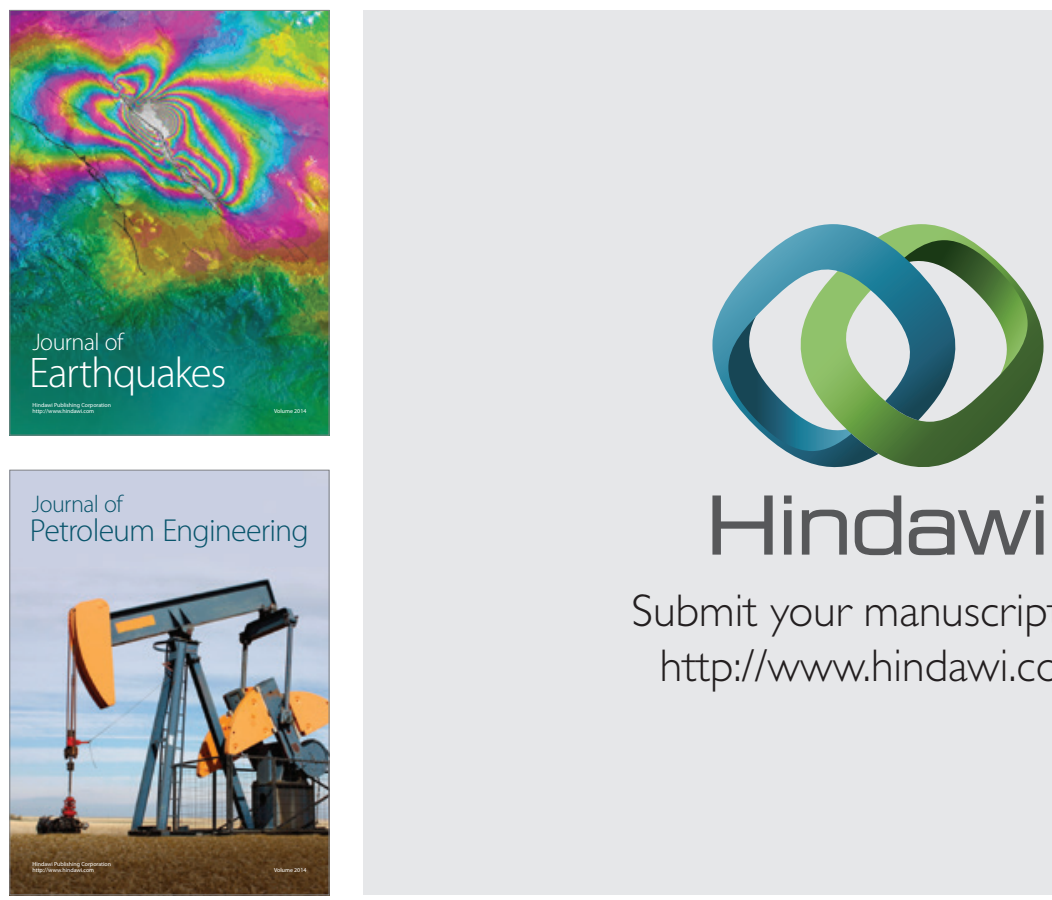

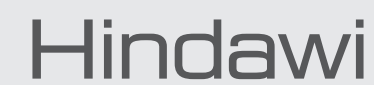

Submit your manuscripts at

http://www.hindawi.com
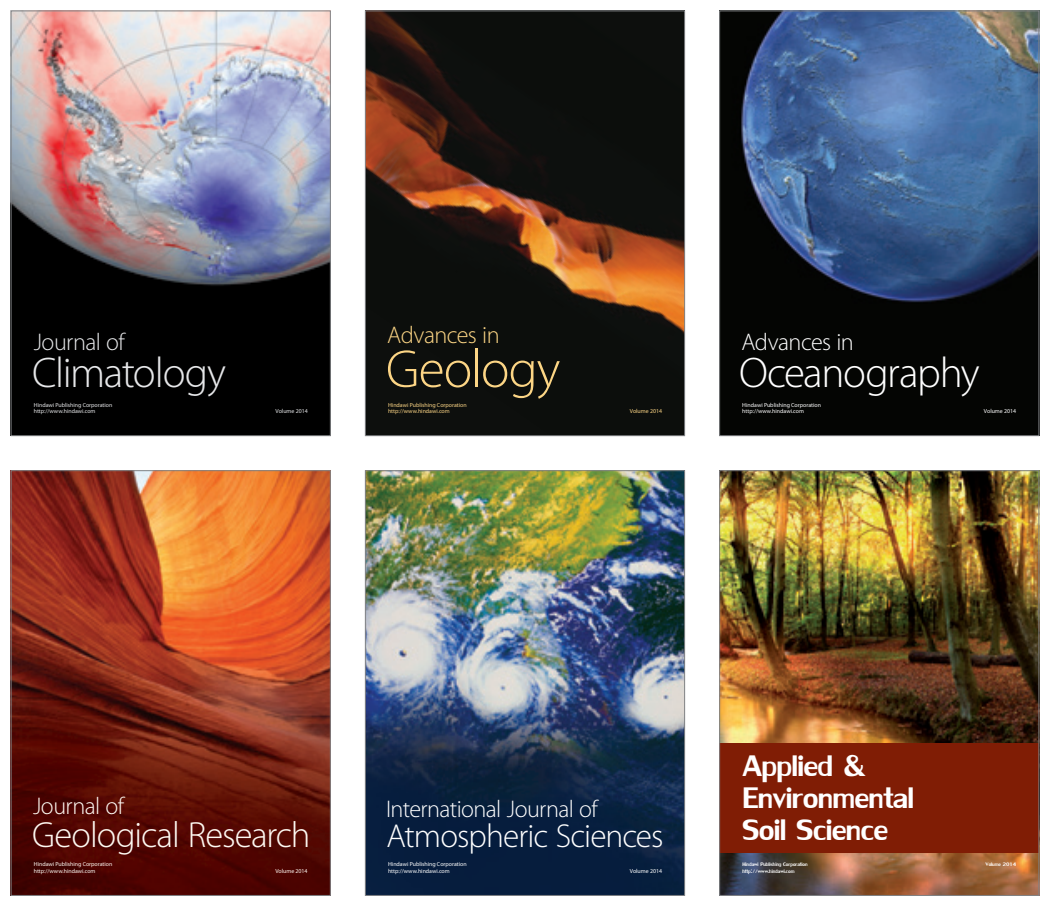
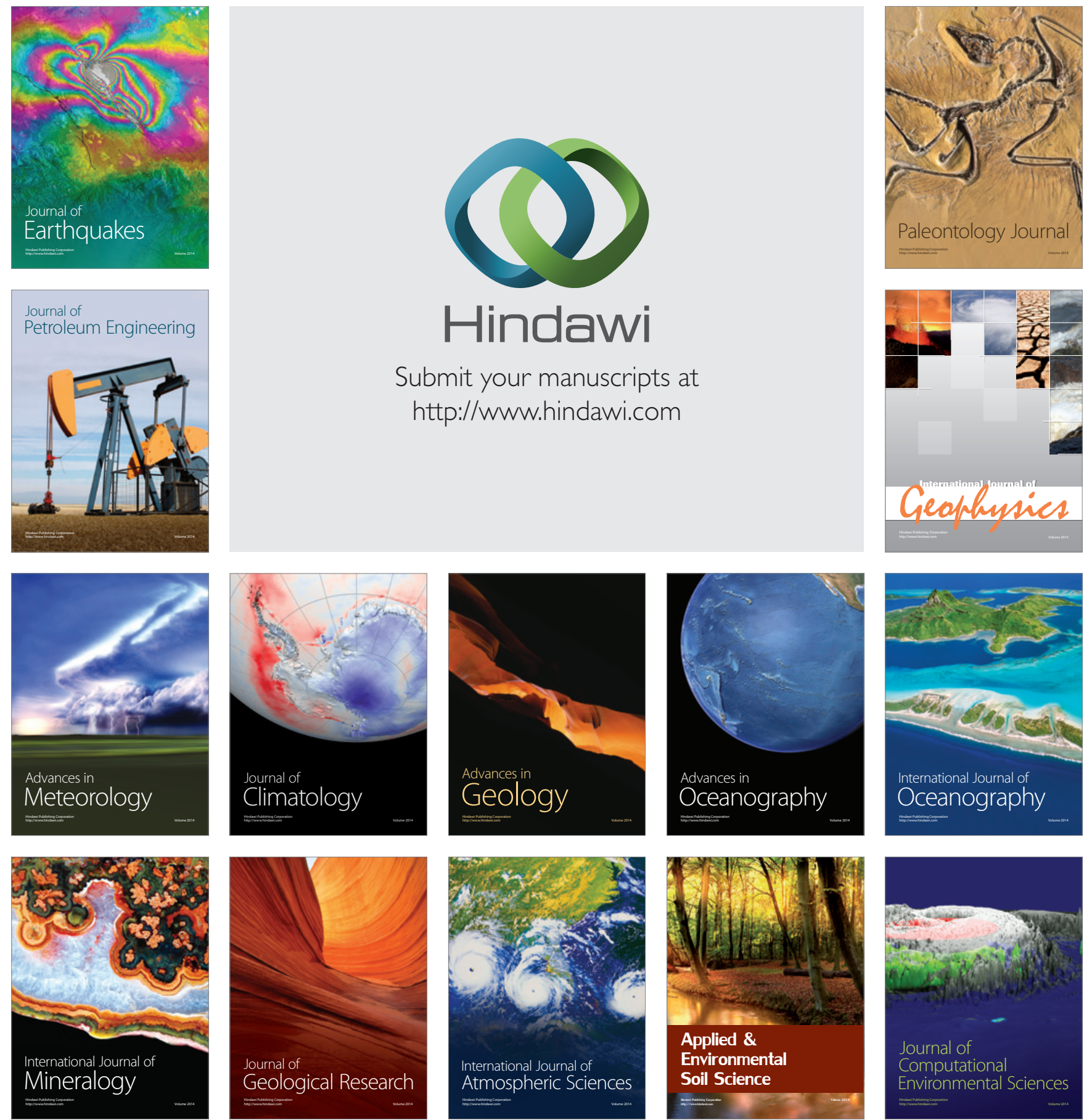